\title{
THE PHENOMENON OF POLITICAL MULTIBRANDING IN MODERN UKRAINE
}

\section{Halyna Shchedrova}

\section{INTRODUCTION}

Branding has become an integral part of modern economic relations, marketing, information and cultural sphere as a process of constant commitment to a particular product (both tangible and intangible). Policy has not been an exception in the development of appropriate strategies, the formation of tools and approaches to branding on globally, regionally and personalized levels. Political branding is one of the determining factors in the transformation of the political environment, the search for optimal ways of positioning, recognizability and methods of competition. In addition, branding can contribute to the development of modern political culture, communication in society, a consolidating marker in the formation of a balanced system of relations between government and civil society at the state level.

The importance of researching the problem of branding determines the scientific and practical interest in it by domestic and foreign scientists in the context of political culture and consciousness, political communication, political psychology and other fields of knowledge, whose research analyzes conceptual and empirical aspects of formation and implementation brands. The theoretical substantiation of the political brand formed the basis of scientific research of such Ukrainian scientists as $\mathrm{S}$. Veleshun, O. Yevtushenko, G. Kuts, T. Nagornyak, I. Prysyazhnenko, G. Shevchenko, research on branding of the state and territories is carried out by O. Korchagina, N. Lyutko, D. Yatsyuk, branding of political parties N. Lisovska, K. Pavliuk, A. Rudenko and others.

It is relevant such areas of activity as the search for optimal brands of the state, territories, state institutions in conditionals of choosing a stable and consistent state strategy in Ukraine. Equally important is the development of practices in the formation of political brands of parties, organizations and other political actors. This complex course of processes determines the feasibility of using the concept of "political multibranding", the essence of which requires categorization taking into account the current state of domestic policy.

Political brand is an element of competition for power. Its creation is part of the study of the electoral field, target audiences, the dominant agenda of society. Ukraine has already had enough meaningful cases in the 
implementation of political branding. The study of their specificity makes it possible to determine the level of sustainability of the political institutional sphere and in general the state of democratization of political power relations.

\section{Branding as a technology and tool of the formation recognizability and commitment to the object}

Branding was borrowed from the economic sphere as an activity to create a lasting commitment to a product / object to socio-political categories. The concept and process is used in terms of creating a brand of the state, country, territory, personal brand and so on in the political plane. All these types of branding are widespread in the West and are experiencing an active phase of formation in modern Ukraine.

The concept of "brand of the state" is often associated with such phenomena of cultural and informational perception as "image of the state" and "vision of the state". However, if the first is defined as a set of rational and emotional ideas arising from the comparison of all features of the country, the historical experience of its population, the forms of communication it uses, the second is a product of centuries-old synthesis in the public consciousness and culture of the nation of some original ethno-national characteristics ${ }^{1}$. In turn, the "brand of the state" is a collective image of a particular political system, parties, politicians and statesmen, which corresponds to reality and is associated with the objective interests of the nation with its unique features.

State, national, regional and global branding are not linear and single-order categories. Thus, state branding is a type of political branding, and global, national and regional are the areas of territorial branding, which are aimed at improving the perception of national sovereignty and its constituent regions by residents and external observers. The branded items are the state as a political institution in the first case, and in the second the territory with "claims" of different levels².

Branding is an important aspect of communication. A well-known expert in the field of branding of states and territories S. Anholt emphasizes this. In his opinion, the brand is a general context of external communication and reputation of states ${ }^{3}$. Analyzing the factors influencing the popularity of the state (culture, tourist interest, politics, economy, social climate, etc.), the British scientist formed a rating of attractiveness of countries, the calculation of which was based on the following components:

${ }^{1}$ Шевченко Г. Політико-інформаційний вимір державного брендингу України. Автореф. на здобуття наук. ст. кан. політ. н. КНУ ім. Т. Шевченка, 2009. С. 8-9.

${ }^{2}$ Нагорняк Т. Брендинг територій у сучасних політичних практиках. Грані. 2014. № 3 (107). C. 54.

${ }^{3}$ Anholt A. Beyond the Nation Brand: The Role of Image and Identity in International Relations. URL: www.exchangediplomacy.com. 
- exports (estimates of the inhabitants of different countries about goods that they either choose or ignore);

- governance (public opinion on the competence and openness of the country's leadership - it is a measure of individual perception of government; assessment of justice, democracy, environmental protection, etc.);

- culture and heritage (assessment of the historical heritage of the country and the state of its modern culture);

- tourism (level of interest in visiting the country, interesting and attractive tourist attractions);

- investment and immigration (attractiveness of the country for living and investing in the economy);

- people (their education, openness, or vice versa their hostility and discrimination $)^{4}$.

Components of the measurements of the index of national brands of the world "Future Brand Country Brands Index" complement the methodology of state branding. They are based on a kind of evaluation hierarchy of decisions, which ultimately give an individual assessment of the state brand:

- human awareness of the existence of the country and its capabilities;

- associations and stereotypes about the country;

- business potential, quality of life and value system;

- respect, authority of the country;

- the decision to visit the country and the factors that prompted its adoption;

- a person's desire to tell acquaintances about the country ${ }^{5}$.

Another related concept is the "branding of territories", which's been perceived by modern political science in several forms. First, it can be identical to the direction of policy as a long-term and holistic policy of development of the territory in order to self-organize on a value basis as a policy actor ${ }^{6}$. Secondly, the branding of territories acts as a political technology, the relevance of which increases during election campaigns, it is also a kind and component of personal and group strategies of capital conversion in the political field.

Spatial branding is embodied in the brand of the country as a set of characteristics (name, sign, image, symbol, term, slogan, etc.), which united

${ }^{4}$ Anholt A. Beyond the Nation Brand: The Role of Image and Identity in International Relations. URL: www.exchangediplomacy.com.

${ }^{5}$ Баровська А. Брендинг держави в контексті Євро-2012: виклики та перспективи. Аналітична доповідь. НІСД. 2011. URL: http://www.niss.gov.ua/content/articles/files/evro 2012-ff728.pdf.

${ }^{6}$ Нагорняк Т. Брендинг території як державна та регіональна політика: Монографія. “Ноулідж”. 2013. С. 70-75. 
of the idea of the country itself, contain exclusive and positive characteristics of the country and distinguish it from others in the world ${ }^{7}$.

The concept of "political brand" is mainly perceived as a characteristic of certain political forces and institutions, it includes a range of relationships, attitudes and rational constructions that have developed in society regarding the actions and statements of the branding entity. Political brand includes a number of mandatory components as a multicomponent construction, in particular, slogan (verbal symbols when positioning a brand), cover brand (background on which the slogan is placed), visual brand (shape, geometric shape) and personal brand filters, like political actors (brand personalities if they are direct political leaders, or brand faces if they are a public representative of a political force, etc.).

The effectiveness of a political brand is measured by such characteristics as:

- brand strength, ie the ability to dominate within a certain political space;

- compliance of the brand with the needs and interests of the audience;

- ability to increase the number of supporters and spheres of influence;

- the level of public support and the probability of choosing a specific political entity if there are other alternatives;

- the degree of popularity of a political brand, measured by quantitative characteristics ${ }^{8}$.

The directions of realization of a successful brand were once described by the Swedish conceptualist T. Ged. His theory of "four-dimensional branding" includes rational, emotional, spiritual and social directions. In the work "4-D Branding" he emphasized that branding in the XXI century requires perception and imagination, as well as the constant development of relationships between supplier and consumer of the product. What is important is the author's thesis that today brands are built around relationships, not around things or products. Thus, from the sphere of physical brands moved to the sphere of psychological and political. It's explained as brands are now associated with the values with which the individual identifies, and therefore values define brands ${ }^{9}$.

Instrumental aspects of branding are the subject of scientific research and approbation workshops. Thus, the researcher L. Vincent in his work "Legendary Brands" explores "brand mythology", understanding it as a "brand story that creates a kind of existential connection between the

\footnotetext{
${ }^{7}$ Колесницька Н. Територіальний брендинг: науково-методологічні підходи до визначення та формування. Наукові праці. Політичні науки. 2012. № 185. Т. 197. С. 48.

${ }^{8}$ Поветьев П. Бренд коммуникация в публичной политике: концептуальные основы. URL: http://www.nirsi.ru/analitic/Brand-kommunikaciya_v_publichnoy politike.pdf.

${ }^{9}$ Гэд T. 4D брэндинг: взламывая корпоративный код сетевой экономики. Манн, Иванов и Фербер, Стокгольмская школа экономики в Санкт-Петербурге. 2005. 232 с.
} 
consumer and the brand"10. The American strategist D. Atkin in his book "The Cult of Brands" argues for the existence in modern society of "brand communities" that are supporters of brand cults ${ }^{11}$. The author clearly demonstrates how the commercial sphere has become a certain "religion", and the belief of it grows with each demonstration of the idea and value of the brand.

According to the French culturologist J. Baudrillard, in order to become a desirable object of consumption, every thing must become a sign. The scientist introduces the concept of "simulacrum". It's a construction in which the difference between real and imaginary disappears. In essence, J. Baudrillard interpreted the whole modern world as a world of ideas that correlate little with reality, but those that are perceived as not just reality but "super reality" . The basic tool in building a brand with such an approach should be advertising - a kind of brand discourse. An imaginary concept is created with the help of constant reproduction of advertising images and plots, which is easily perceived by the public consciousness as reality.

Ukrainian researcher G. Kutz points out that influencing the recipient's behavior is the most important goal of brand management. That is why branding is actively used in the modern political space, in particular, in electoral processes, in the positioning of political parties, the formation of the image of political leaders, the creation of the image of the state and so on. According to the author, this is due to the fact that in modern conditions, the brand is a long-term unique competitive advantage ${ }^{13}$. Indeed, brands establish a trusting link between the electorate and the political class, as brands provide certain guarantees not only about the expectations of the recipients, but also about the predictability of the behavior of a particular political force or political leader.

The basic principles of political branding were formulated by the French political scientist and political consultant J. Segel. These principles underlie the direct political activity of their author, who claimed that he "created brands in the image and likeness of people, just as God created the latter. But people are mortal, and brands can count on immortality"14. J. Segela emphasized that today states must act by analogy with global corporations,

${ }^{10}$ Винсент Л. Легендарные бренды: Раскрученные рекламные мифы, в которые поверил весь мир. ФАИР-ПРЕСС. 2004. С. 26.

${ }^{11}$ Аткин Д. Культ брэндов: как сделать покупателя единомышленником. АCT: Транзиткнига. 2005. С. 163.

${ }^{12}$ Бодрийяр Ж. Злой демон образов. Искусство кино. 1992. № 10. С. 65-69.

${ }^{13}$ Куц Г. Ідентичність бренду: політико-регіональний вимір. Гілея: науковий вісник. 2013. № 73. C. 306-308. URL: http://nbuv.gov.ua/UJRN/gileya_2013_73_139.

${ }^{14}$ Вице-президент HAVAS Жак Сегела: Креативность - это командная игра, а не одиночный спорт. URL: https://www.sostav.ru/publication/vitse-prezident-havas-zhak-segelakreativnost-eto-komandnaya-igra-a-ne-odinochnyj-sport-27283.html. 
which focus on creating brands and intangible assets, because in today's world the brand is valued much higher than factories and technologies. The role of a leader is very important for a successful brand, because just as a political party cannot exist without its hero, so people in the media age need bright images. According to the political scientist, first of all the voter votes for the personality, and not for the program at all. A political party that does not have a standard-bearer and a bearer of an ideal is doomed to failure. Success is impossible if the party does not have a leader whose image corresponds to his electorate ${ }^{15}$

Ukrainian political scientist A. Rudenko identifies such party technologies which's based on the marketing strategy of positioning Ukrainian political parties. They are:

- naming (development of the name of a political party);

- definition of brand persons of the party;

- creation of an ideological platform and formation of a party program;

- development of design of party symbols and advertising products;

- party branding ${ }^{16}$.

Comprehensive using of these technologies provides both the formation of the party brand and the construction of the party image as the technology of creating a certain image, which involves the introduction of information about the party, the formation of a set of problems to be positioned, party identification with its audience segment ${ }^{17}$. It is also important to distinguish between the scientific categories of "party brand" and "party product", because the party brand is rooted in the mass consciousness, symbolic content, emotional load and the ability to combine several political goods. Party brand is a result of political marketing. It is interpreted by A. Rudenko as a kind of unique proposal of a particular political party ${ }^{18}$.

Branding technology for a political party is a necessary condition for the formation of the target audience, and hence the future electorate. Creating a political brand is one of the main resources for successful participation in a competitive political struggle, because, as already noted, in the modern political world there is a struggle of brands, not ideologies or programs.

\footnotetext{
${ }^{15}$ Сегела Ж. Национальные особенности охоты за голосами: 8 уроков для кандидата победителя. Вагрус. 1999. С. 52.

${ }^{16}$ Руденко А. Технології політичного маркетингу в діяльності політичних партій України. Дис. на здобуття наук. ст. канд. політ. н. ДНУ ім. Василя Стуса. 2017. С. 27.

${ }^{17}$ Сакрієр О. Технології конструювання іміджу лідера політичної партії у парламентських виборчих кампаніях України. Автореф. дис. на здоб. наук. ст. канд. політ. н. Чернів. наи. університет ім. Ю. Федьковича. 2012. С. 8.

${ }^{18}$ Руденко А. Технології політичного маркетингу в діяльності політичних партій України. Дис. на здобуття наук. ст. канд. політ. н. ДНУ ім. Василя Стуса. 2017. С. 3.
} 


\section{Multibranding as a phenomenon of Ukrainian politics}

The concept of branding covers areas from art to production and politics in the modern world. Despite the fact that politics has the least specificity, this aspect of public life gives the biggest dividends, in particular, in the form of control over both art and production. Branding as an activity to create a lasting commitment to a particular product in the field of economics entered the political plane of the Western world in the middle of the twentieth century and began to be actively used in domestic practices in the early 2000s. However, we consider the categorization of this concept exclusively in the dimension of product marketing strategies not sufficiently justified, especially given the specific features of modern public policy in Ukraine and public policy in the international arena.

Therefore, it is proposed to use the term "political multibranding" in the sense of a set of measures and techniques aimed at simultaneously ensuring the recognition and formation of a favorable attitude to the subject of political activity: the state, political leaders, their teams, related structures and more. The expediency of the proposed definition is due to the formation of such a political space in Ukraine, where public policy participants in addition to the usual elements in the form of public organizations or youth "wing" of parties may contain stable media products, power groups, structures that are identified with political force.

The practice of introducing multi-branding has been embodied both at the state and regional levels, as well as in modern political projects, in particular, parties, individual politicians, etc. This can be clearly seen in the example of an active campaign to form and promote a single advertising brand of Ukraine, which was approved by the Cabinet of Ministers of Ukraine in May $2018^{19}$.

The brand was proposed by the Ukrainian agency "Banda" in the framework of the Commission for the Promotion of Ukraine at the Ministry of Information Policy of Ukraine, as well as on the basis of proposals from British partners. According to the Ministry of Information Policy, they worked on the development of the brand for almost a year. They were created several variants of concepts of promotion of Ukraine, which were shown to six focus groups in Great Britain, Germany and Poland. The experts concluded that the new, and in fact the first, state-approved brand was designed to improve the world community's perception of Ukraine, which is

\footnotetext{
${ }^{19}$ Уряд схвалив новий бренд “Україна Зараз”, що забезпечить єдиний стиль презентації держави в світі. Урядовий портал. URL: https://www.kmu.gov.ua/news/uryad-shvaliv-novijbrend-ukrayina-zaraz-sho-zabezpechit-yedinij-stil-prezentaciyi-derzhavi-v-sviti.
} 
currently "associated with three things - revolution, corruption and war",20 (Fig. 1). Also among the goals of promoting the approved brand was to attract investment to the country and improve tourism potential. The logo was described as dynamic, open and positive - the way the world should see Ukraine right now.

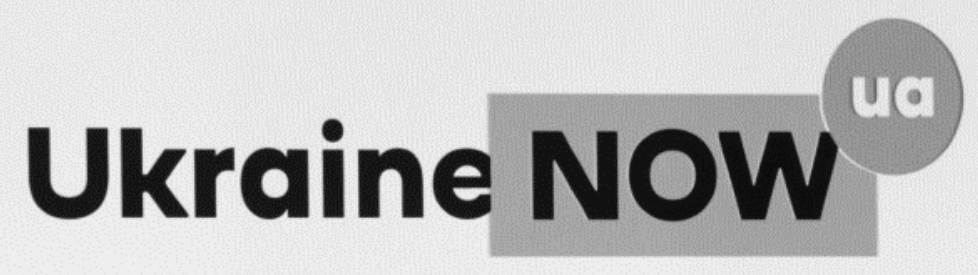

Fig. 1. The single brand of Ukraine "Ukraine NOW UA"

The brand of Ukraine was historically formed in Soviet times. It positioned the country as a "granary" of the territories of the socialist camp. This association also identified markers of the use and perception of Ukraine, and the appeal of the world community to it. Such a tradition determined the consumer attitude to Ukraine and, as a consequence, the formation of such clichés as "raw material base", "appendage" and so on. The new logo and its presentation indicate that the brand is developed for a foreign audience. In her imagination, a new visualization of Ukraine was to emerge without a wellestablished symbolic perception (sunflowers, ornaments, deer, etc.). Given that the content of the brand (the descriptive part of the underlying meanings), has not been disclosed, we assume that the primary goal is to put Ukraine on the agenda of the international community. This is a kind of continuation of the then diplomatic activity of the state leadership and a reasonable need for the time when the country was experiencing acts of military aggression in the Donbass.

${ }^{20}$ Кізілов С. В України з'явився рекламний бренд. Украӥнська правда. 2018. URL: https://www.pravda.com.ua/news/2018/05/10/7179891. 
Due to the formation of a holistic and meaningful brand of the state, it is possible to ensure the implementation of a number of important (urgent and strategic) functions. At one time, this aspect of branding was revealed by Ukrainian researcher G. Shevchenko. In her dissertation research, she substantiated the thesis that state branding allows to spread both universal features of Ukrainian political culture (support of democratic values; rule of law; promotion of the idea of good, justice, guarantees of life rights, protection of citizens and their freedoms; formation of European identity) and and original (unique) national worldviews that demonstrate national-state identity (creation and promotion of cultural and information products that contribute to the positioning of the state brand in all its manifestations) ${ }^{21}$.

Multiculturalism and multinationality of Ukraine is one of the winning factors in promoting such a brand in the world in the context of forming a state brand, because taking into account all regional authenticity shows the support of the country's ethnic population at the state level. It is also another tool for promoting Ukraine's tourism brand on the model of other European countries, whose tourist regions have become recognizable in the world due to a planned and systematic policy, providing, in particular, economic and financial dividends and reputational advantages in the international arena.

Given the above arguments, it can be argued that the consequences of successful implementation of state branding of Ukraine should be:

- promotion of the political ideology of the state in the international arena;

- strengthening the position of Ukraine in the world political and cultural space;

- improving the country's competitiveness in the field of foreign economic relations, tourism and cultural exchange;

- effective formation of national identity;

- consolidation of internal resources and international support in counteracting external challenges and military threats, which are an urgent problem of modern Ukraine.

As a result, Ukraine must find its place with a positive associative number. The current emphasis in the implementation of the state brand is focused primarily on overcoming the negative, or stereotypical, perception of Ukraine in the world, rather than on the presentation of benefits and achievements that would be unique or have a positive image potential. Accordingly, over time, the state brand should be supplemented with a list of what Ukraine is right now (Ukraine NOW).

\footnotetext{
${ }^{21}$ Шевченко Г. Політико-інформаційний вимір державного брендингу України. Автореф. на здобуття наук. ст. кан. політ. н. КНУ ім. Т. Шевченка, 2009. С. 3.
} 
The official branding of territories (regions, communities, cities) has been continued since 2016 along with the formation of the state brand in Ukraine. In contrast to the national trends in the regions, the approach is more traditional - both in the visual part and in relation to the selected slogans. For example, Khmelnytsky region began to position itself as a "crossroads of elements and stories", while choosing an original ornament. Transcarpathia has secured the brand of "land close to the sun" with a corresponding mountain landscape on the logo. It's became natural the symbolic image of a lion on the brand of Lviv region. Cherkasy, Kyiv, Vinnytsia, other oblasts, cities, united territorial communities and settlements have started to develop their official brand. However, it should be noted that the attention of the regions is focused exclusively on finding their tourist brands, which speaks volumes about the purpose of such searches.

Despite the fact that the category "brand" has aproached recently in relation to the territories of Ukraine, but regions and cities still had individual perceptions and established statuses, such as Luhansk region is the dawn of Ukraine, Kharkiv is the student capital, Lviv is cultural capital, Donetsk region associated with mining, and Odesa associated with the sea, Kyiv is the mother of Russian cities and more. Such definitions are dictated by historical development, the specifics of infrastructure, socio-cultural dominants and other factors. Obviously, these are traditional, and therefore autonomous brands that do not lie in the plane of implementation of the relevant state policy. We assume that these symbols will coexist for a long time with the results of modern branding in Ukraine.

Usually, state brands are purposefully formed by relevant companies and specialists working on a tender basis. For example, in Scotland the national brand was promoted by the marketing company CLK, which offered Scotland the Brand to the world. In Poland, it is the Corporate Profiles DDB agency, which has developed a national logo, slogan and marketing campaign in general. There is no single national brand promotion strategy in Canada Garneau, Wurstlin, Philp: Brand Engineering, which offers to advertise Canada as a "junior version of the United States", and Taxi Advertising \& Design, which focuses on innovation and creative potential of the country ${ }^{22}$.

The criteria for evaluating and measuring brands are: the value of the brand (state branding), and the level of recognition, electoral and interelectoral support ( a brand of a political entity).

Every year, the international company "Brand Finance" publishes a report on the value of national brands in the world. According to the report "Brand

\footnotetext{
22 Державна політика у сфері національного брендингу: Інформаційна довідка, 2016. URL: https://www.radaprogram.org/sites/default/files/infocenter/piblications/29157.pdf.
} 
Finance Nation Brands 2019", the United States continues to dominate the world rankings ${ }^{23}$. From 2018, the second and third places remain unchanged. They are China and Germany. Also in the top ten are Japan, Britain, France, India, Canada, South Korea and Italy. The value of these national brands ranges from 27.75 billion dollars. The United States in the United States to 2.1 billion dollars. USA in Italy. In the Top 100 world brands, Ukraine ranked 56th in 2019, rising by two positions compared to 2018. Its neighbors on the scale "Brand Finance" - Luxembourg and Greece. Perception of Ukraine as a developing brand is the achievement of an active process of branding, presentation of the country at the highest level of international relations, the correct definition of priorities.

Another area of multibranding in Ukraine is the formation of brands of political actors (parties, organizations, political leaders, their teams, etc.). Ukraine has several illustrative cases in this direction, which, have different degrees of effectiveness. Back in the early 2000s, the country began to embody and develop the brand of "regions", which was institutionally embodied in the activities of the political party "Party of Regions", its youth wing ("Young Regions"), a clear identification with industrial regional centers (despite the headquarters was located in Kyiv), visual identification with a white and blue background and personalized perception through the leaders of the "Party of Regions" (V. Yanukovych, B. Kolesnikov, M. Azarov, $\mathrm{O}$. Vilkul, etc.). The successful period of multi-branding is characterized by victories in two parliamentary elections (2006 and 2007), winning 187 seats in the Verkhovna Rada as a result of the 2012 elections, the victory of the party leader in the 2010 presidential election, expulsion from the party of its leading leaders, withdrawal from the party of hundreds of thousands of its members in all regions ${ }^{24}$. Today, the brand of "regions" has lost both credibility and trust. The return of part of the team to the political sphere is accompanied by the implementation of completely different political brands ("Our Land", "Opposition Bloc", "Opposition Platform - For Life", etc.).

Another example with the opposite background is the Right Sector. This is a brand that has in its structure: the political party "Right Sector", the Voluntary Ukrainian Corps "Right Sector", the public organization "Right Youth". Officially, the structure has a common name National Liberation Movement "Right Sector" 25 . The goals of the organization are embodied in

\footnotetext{
${ }^{23}$ Brand Finance Nation Brands. URL: https://brandfinance.com/images/upload/ nation_brands_100_2019_free_1.pdf.

${ }^{24}$ Центральна виборча комісія: Офіційний веб-сайт. URL: https://www.cvk.gov.ua/ vibory_category/vibori-narodnih-deputativ-ukraini.html.

${ }^{25}$ Національно-визвольний рух "Правий сектор": Офіційний веб-сайт. URL: https://pravyysektor.info/pro-ruh.
} 
the official slogans: "A force that protects!", "Born on the Maidan! Tempered by war!","For the Ukrainian Independent Conciliar State!". The colors of the brand are red and black.

The "Right Sector" is a successful example of a multi-brand, because in the process of constant transformation, the organization has retained all the functional segments of its structure. It's being started its existence during the Euromaidan (November 2013) in the format of a situational association of right-wing activists, the movement was transformed into a volunteer battalion (July 2014) and took part in hostilities in the east of the country. With the beginning of preparations for the 2014 parliamentary elections, the Right Sector political party is being separated from the paramilitary formation of the Right Sector State Unitary Enterprise. The election to the Verkhovna Rada resulted in $1.8 \%$ of the electorate's support and only one seat in parliament that of party leader D. Yarosh, who won in a single-member constituency ${ }^{26}$. One of the reasons for the party's loss in the elections is the lack of consolidated cooperation with other right-wing political forces and candidates (Svoboda, Congress of Ukrainian Nationalists), which also failed to get into the Verkhovna Rada. The formation of a joint brand would minimize reputational losses and implement a successful election campaign (these political parties received a total of $6.56 \%$ of the vote $)^{27}$.

Despite the lack of success in political activities, the Right Sector remains an active participant in the socio-political life of Ukraine, supporting the functioning of all its cells and structural units. The organization has been in the spotlight through a number of lawsuits involving the organization's fighters during 2015-2017. This only added points in the recognizability rating to the structure, which already has a well-established positioning.

Finally, consider one of the most successful cases of multibranding, namely the format "Servants of the People", the image characteristics of which had presented in the film of the same name 3.5 years before the start of public policy. The implementation of the multi-branding strategy began with the registration of the "Servant of the People" party at the end of 2017. In 2019 , one of the party's founders V. Zelensky won the election of the President of Ukraine, receiving $73.22 \%$ of the vote ${ }^{28}$. Subsequently, the

${ }^{26}$ Центральна виборча комісія: Офіційний веб-сайт. URL: https://www.cvk.gov.ua/ vibory_category/vibori-narodnih-deputativ-ukraini.html.

${ }^{27}$ Центральна виборча комісія: Офіційний веб-сайт. URL: https://www.cvk.gov.ua/ pls/vnd2014/wp300pt001 f01=910.html.

${ }^{28}$ Центральна виборча комісія: Офіційний веб-сайт. URL: https://www.cvk.gov.ua/ pls/vp2019/wp300pt001f01=720.html. 
Servant of the People political party $(43.16 \%)$ also won the parliamentary elections, forming a mono-majority in the Verkhovna Rada ${ }^{29}$.

Today, the "Servant of the People" brand is a political party, a faction in the parliament, representations in the regions, and an active online platform, the "Servant of the People" - Zelensky's Team. The structure was named "Ze-Komanda" (after the first part of the name of the leader of the organization V. Zelensky) in general and formally,. The branding strategy, especially in its visual and verbal symbols, was quite systematic and logical: the color of the brand is green, the slogans are "President / MP is a Servant of the People", "Let's make them together", "Spring is coming - we will jail", "Let's create a country dreams "and others. In the context of the political process, the slogans changed according to the situation, the priorities of the President and parliamentarians.

Positive experience of branding "Servants of the People" is analytical work with the requests of the target audience, whose needs formed the basis of political slogans, consolidation of protests and frustrations in the policy of the state and turning them into high political dividends, successful choice of brand personalities which don't have a negative perception of ordinary citizens (V. Zelensky as a leader of a political force, D. Razumkov as a speaker and brand face of the election campaign). The described brand at the present stage is undergoing development, forming a regional office and adjusting the relevant representatives in the central government. In the future, the structure of the multibrand will be branched out with further specification of functions and tasks.

Considering the various formats of multibranding in Ukraine (from national to institutional) we can trace the political component in each of these processes. This is an integral feature of the transition period of state formation, when politicization accompanies the flow of all aspects of society. Thus, it is fair to say that all forms of branding in our country are somehow political. Moreover, this cases are examples of complex multilevel formation of brands as a kind of political multibrands.

Given the established forms of branding in Ukraine, it can be presented in terms of the following levels:

- macro level - branding of the state, country, separate territories (regions);

- local (institutional) - branding of political parties, public organizations, state institutions or structures (such as the branding of the New Police or an attempt to rebrand Ukrzaliznytsia);

\footnotetext{
${ }^{29}$ Центральна виборча комісія: Офіційний веб-сайт. URL: https://www.cvk.gov.ua/pls/ vnd2019/wp300pt001f01 $=919 . \mathrm{html}$.
} 
- personal - the formation of brand personalities individually or as a member of a political team.

Among the shortcomings that can be clearly seen in political multibranding in Ukraine, we note the predominance of form over content, when only the visual part is subject to update and less often - strategies, forms of their implementation, means of inter-institutional communication. By the way, branding is one of the forms of such interaction, because it always acts as a carrier of information. Another problem is also related to the communication sphere, as it is the weak interaction of political institutions and entities with the target audience, taking into account the needs and expectations of which is the key to successful brand building. Deformed or limited channels of communication between the bearer of the brand and the consumer, ie society, often have consequences not only in the form of rejection of the brand, but also such as deep crises in the state. Domestic modernity has several such examples ("Orange Revolution", "Revolution of Dignity"), which were preceded by large-scale public frustrations in the state course, political decisions and actions. Issues of overcoming and correcting such shortcomings should become part of further theoretical developments and empirical research on multibranding in Ukraine.

\section{CONCLUSIONS}

Brand formation from the state to a political party is an urgent requirement and need of the time, in which marketing strategies are part of all spheres of human community. The implementation of state branding is allown to ensure national interests by implementing its various models in interstate cooperation. In addition, the creation and support of state brands contributes to the formation of political identification of the population, adequate assessment of political alternatives and more. Currently, branding as an activity to create a lasting commitment to the subject, the reception of its optimal positioning and a tool to ensure visibility is carried out at the level of the state, country, territory, political institutions and actors.

Today, Ukraine is on the path of developing and implementing branding strategies at all levels, in particular, in the context of developing a policy of state support for the process of creating positive brands of the country and its regions. Such multi-vector branding, especially in the context of creating political brands, has led to the expediency of categorizing such a phenomenon as "political multibranding". It is defined as a set of measures and techniques aimed at simultaneously ensuring the recognition and formation of a favorable attitude to the subject of political activity: the state, political leaders, their teams, related structures, etc. At the same time, in the conditions of long political transition and transitive society, multibranding in Ukraine is rather 
asymmetric in terms of the ratio of concepts and real political practice. The transformation of political institutions focuses on visual branding, rather than on meaningful updating of the structure and approaches in its activities.

Domestic experience in brand formation has several successful cases, which are either developing (state brand "Ukraine NOW"), or have long-term and justified political success (brand "Party of Regions"), or implemented using modern and non-standard means of multibranding (case of political force "Servant of the People").

If the state multibranding is designed to promote the development of export, educational, investment, tourism, infrastructure and other potentials, the creation of brands in the party-political space will provide strategic planning of the political product for the long term.

\section{SUMMARY}

There are analyzed theoretical and applied aspects of formation and realization of branding of the states, the countries, territories, political institutes The correlation of the concepts "image of the state", "image of the state", "brand of the state" is understood as the aggregate image of a certain political system, parties, politicians and statesmen, which corresponds to reality and is connected with objective interests its unique features by the latter.

There're studied approaches to the evaluation of different types of brands, criteria for their effectiveness and popularity (such as the approach of S. Anholt). The research substantiates the idea that political branding is an important element of communication, because each brand is always a carrier of information that society either perceives or by its non-perception causes changes in the entire branding strategy.

It's given the specifics of branding in modern Ukraine, so it is proposed to use the concept of "political multibranding", categorizing it as a set of measures and techniques aimed at simultaneously recognizing and forming a favorable attitude to the subject of political activity: the state, political leaders, their teams, related structures etc.

Among the practices of forming political brands, the ones that have experience of complex brand formation, which has proven its effectiveness, are considered. They are based on the analysis of various forms of branding in Ukraine, and there are distinguished its macro level (state, territories), local or institutional level (parties, public organizations, state institutions) and personal level (political leaders).

\section{REFERENCES}

1. Аткин Д. Культ брэндов: как сделать покупателя единомышленником. АСТ: Транзиткнига. 2005. 272 с. 
2. Баровська А. Брендинг держави в контексті Євро-2012: виклики та перспективи. Аналітична доповідь. НІСД. 2011. URL: http://www.niss.gov.ua/content/articles/files/evro2012-ff728.pdf.

3. Бодрийяр Ж. Злой демон образов. Искусство кино. 1992. № 10. C. $64-70$.

4. Винсент Л. Легендарные бренды: Раскрученные рекламные мифы, в которые поверил весь мир. ФАИР-ПРЕСС. 2004. 336 с.

5. Вице-президент HAVAS Жак Сегела: Креативность - это командная игра, а не одиночный спорт. URL: https://www.sostav.ru/ publication/vitse-prezident-havas-zhak-segela-kreativnost-eto-komandnayaigra-a-ne-odinochnyj-sport-27283.html.

6. Гэд T. 4D брэндинг: взламывая корпоративный код сетевой экономики. Манн, Иванов и Фербер, Стокгольмская школа экономики в Санкт-Петербурге. 2005. 232 с.

7. Державна політика у сфері національного брендингу: Інформаційна довідка, 2016. URL: https://www.radaprogram.org/sites/ default/files/infocenter/piblications/29157.pdf.

8. Кізілов Є. В України з'явився рекламний бренд. Украӥнська правда. 2018. URL: https://www.pravda.com.ua/news/2018/05/10/7179891.

9. Колесницька Н. Територіальний брендинг: науково-методологічні підходи до визначення та формування. Наукові пращі. Політичні науки. 2012. № 185. Т. 197. С. 47-50.

10. Куц Г. Ідентичність бренду: політико-регіональний вимір. Гілея: науковий вісник. 2013. № 73. C. 306-308. URL: http://nbuv.gov.ua/ UJRN/gileya_2013_73_139.

11. Нагорняк Т. Брендинг території як державна та регіональна політика: Монографія. “Ноулідж”. 2013. 367 с.

12. Нагорняк T. Брендинг територій у сучасних політичних практиках. Грані. 2014. № 3 (107). С. 53-58.

13. Національно-визвольний рух "Правий сектор": Офіційний вебсайт. URL: https://pravyysektor.info/pro-ruh.

14. Поветьев П. Бренд коммуникация в публичной политике: концептуальные основы. URL: http://www.nirsi.ru/analitic/Brand-kommunikaciya _v_publichnoy politike.pdf.

15. Руденко А. Технології політичного маркетингу в діяльності політичних партій України. Дис. на здобуття наук. ст. канд. політ. н. ДНУ ім. Василя Стуса. 2017. 275 с.

16. Сакрієр О. Технології конструювання іміджу лідера політичної партії у парламентських виборчих кампаніях України. Автореф. дис. на здоб. наук. ст. канд. політ. н. Чернів. нач. університет ім. Ю. Федьковича. 2012. $20 \mathrm{c}$. 
17. Сегела Ж. Национальные особенности охоты за голосами: 8 уроков для кандидата - победителя. Вагрус. 1999. 262 с.

18. Уряд схвалив новий бренд “Україна Зараз”, що забезпечить єдиний стиль презентації держави в світі. Урядовий портал. URL: https://www.kmu.gov.ua/news/uryad-shvaliv-novij-brend-ukrayina-zaraz-shozabezpechit-yedinij-stil-prezentaciyi-derzhavi-v-sviti.

19. Центральна виборча комісія: Офіційний веб-сайт. URL: https://www.cvk.gov.ua.

20. Шевченко Г. Політико-інформаційний вимір державного брендингу України. Автореф. на здобуття наук. ст. кан. політ. н. КНУ ім. Т. Шевченка, 2009. 21 с.

21. Anholt A. Beyond the Nation Brand: The Role of Image and Identity in International Relations. URL: www.exchangediplomacy.com.

22. Brand Finance Nation Brands. URL: https://brandfinance.com/ images/upload/nation_brands_100_2019_free_1.pdf.

\section{Information about the author:}

Halyna Shchedrova,

Doctor of Political Sciences, Professor, Head of the Department of Political Science and International Relations, Alfred Nobel University 18, Sicheslavska Naberezhna str., Dnipro, 49000, Ukraine 